\title{
THE IOC EXECUTIVE COUNCIL MeEting, PARIS, MARCh, 1988
}

$\mathrm{T}$ he Intergovernmental Oceanographic Commission holds a full meeting every two years. In alternate years, such as 1988, the Executive Council of the Commission meets to carry out business and to prepare for the full meeting. This year's meeting was held in Paris at IOC Headquarters during March 7-15.

A full U.S. delegation attended, with Paul Wolff, Assistant NOAA Administrator for Ocean Services, as Head of the Delegation. Wolff was assisted by alternates Robert Corell, Assistant Director for Geosciences of the National Science Foundation, and William Erb, Director of Marine Science of the Office of Science and Polar Affairs of the State Department. Other government representatives included Gregory Withee, Richard Podgorny, and Candyce Clark from NOAA, Louis Brown from NSF, and Dorothy Bergamaschi from the State Department. D. James Baker from Joint Oceanographic Institutions attended as an advisor.

The full report of the meeting is available from William Erb's office at the State Department. The meeting agenda covered ocean sciences, ocean services, reports from regional subsidiary bodies, cooperation with other groups, future plans, and recommendations for appointment of a new secretary of the commission.

In the area of Ocean Dynamics and Climate, the Executive Council strongly supported the on-going TOGA and WOCE programs. Angus McEwan, Chairman of CCCO, Gerold Siedler, President of SCOR, and George Needler, Director of the WOCE International Planning Office all reported on various aspects of these programs. There was general agreement that the IOC Technical Committee on Ocean Processes and Climate would have an important role to play in the implementation of WOCE. It was also agreed that there would need to be an accelerated phase for the development of ocean services including IODE and IGOSS if programs such as WOCE and TOGA are to succeed.

In Marine Pollution Research and Monitoring, Neil Andersen, Chairman of the Scientific Committee for GIPME, reported on-going activities and noted the importance of the interaction of IOC programs such as GIPME with the Joint Global Ocean Flux Study and the International Geosphere-Biosphere Program. A cooperative program for the Black Sea was supported.

Michel Vigneaux, Chairman of the IOC/UN Guiding Group of Experts on Ocean Science in Relation to Non-Living Resources reported on the (mainly regional) activities during the past year. The Program has held a number of workshops, and Takahisa Nemoto, Chairman of WESTPAC, announced one on Margins of Active Plates to be held in conjunction with the International Conference on Asian Marine Geology in Shanghai next year. Peter Cook of Australia reported for the Joint Working Group on Post-IDOE Studies of East Asian Tectonics and Resources (SEATAR). He noted that the SEATAR Transect Study was now finishing with publication of the synthesized transects and a science review volume.

Kazuhiro Kitazawa of Japan and from the Secretariat reported on the Working Group on South Pacific Tectonics and Resources (STAR). The STAR study group on age dating has completed its task with the publication of more than 500 age-data from islands and seamounts in the south and central Pacific. The Soviet Union announced plans to send two oceanographic vessels into the western Pacific in late 1988 to investigate tectonics and hydrothermal processes at the Pacific Ocean floor.

As reported by Fernando Robles, an IOC Senior Assistant Secretary, the Ocean Science in Relation to Living
Resources program is continuing its focus on recruitment processes and has added a new thrust on red tides and ocean plankton blooms. This latest thrust builds on two recent workshops in Japan.

For Ocean Services, David Pugh of the IOC Task Team of Experts on the Global Sea-Level Observing System and Director of the Permanent Service for Mean Sea Level noted that considerable progress had been made in setting up a global sea level network in the Pacific and Indian Oceans. Globally, there has been a substantial increase in the number of observations made and stations reporting. The importance of the sea level network was emphasized by many delegates, and there was general agreement that this is one of the important tasks of the IOC.

Nick Flemming, Chairman of the IOC Technical Committee on International Oceanographic Data Exchange (IODE), reported progress in expanding and strengthening the IODE system. One of the important points raised in the discussion of data issues was the proposal presented by Greg Withee of NODC that the U.S. was willing to host a Workshop on Climate Data Management in May-June 1989. This proposal was accepted with enthusiasm by the Council.

Natalie Philippon-Tulloch of the Secretariat noted that a long-term strategic framework for the development of the FAO-IOC-UN Aquatic Sciences and Fisheries Information System is now being developed. The system is currently producing over 30,000 abstracts per year and the product is available on a compact optical disk (CD-ROM) as well as through the standard modes of publication. The departure of Yuri Oliounine of the USSR from the Secretariat was noted with regret by the Council. Dr. Oliounine has contributed greatly to the success of the IODE program.

Yves Tourre, Chairman of the IOC/ WMO Working Committee for IGOSS reported that the IGOSS XBT Ship-ofOpportunity Program seems to be working well. A number of new lines have been identified. Almost 2500 good quality XBT profiles were entered for a Pacific Ocean subsurface thermal analysis during the period of NovemberDecember 1987 within the framework of the IGOSS Subsurface Thermal Structure Pilot Project headed by Warren White of Scripps. R. Hagemayer reported that the International Tsunami Warning System has now been upgraded to include tidal data collection by 27 satellite data-collection platforms, but 
the East Asian part of the system remains substandard.

Regional IOC programs ranging from the Western Pacific (WESTPAC), the Southern Ocean (IOCSOC), the Caribbean (IOCARIBE), the North and Central Western Indian Ocean (IOCINCWIO), and from the south-west Atlantic and the central eastern Atlantic reported on various activities and workshops that had been held. Dale Krause, the Director of the UNESCO's Marine Science Division, reviewed the Division's activities in promoting marine science in developing countries and cooperating with non-governmental marine science organizations.

Christophe Billard, Chairman of the Drifting Buoy Cooperation Panel, emphasized the importance of both the technical issues of drifting buoys (how well they work) as well as the legal issues (what happens when a buoy enters waters under national jurisdiction). These issues were debated at length by the Council and a number of recommendations made.

IOC funding has remained approximately level since 1981, and this has led to frustration among many members, who feel that this level of funding is insufficient to the needs of the Commission. Both the U.S. and the U.K., although no longer member states of UNESCO, have made voluntary compensatory payments. If IOC programs are to meet the needs of the new large programs for ocean services, then there will have to be budget increases. Whether these are likely is not certain in the current economic situation.

The Council urged member states to try to provide support for scientists from developing countries for participation in the Joint Oceanographic Assembly. The JOA will be held in Acapulco. Mexico in August of this year. Siedler noted that the JOAs are the only major interdisciplinary international congresses in marine science, and that this one will be the first to be convened in a developing country.

In preparation for next year's meeting, Manuel Murillo, First Vice-Chairman of the IOC, proposed that the theme of the Bruun Memorial Lectures was agreed to be the application of new technology in ocean monitoring. Four specific topics were proposed: Application of acoustic technologym, applications of multibeam scanners in ocean mapping, applications of remotely operated vehicles for the study of the ocean bottom, and the use of satellite-measured ocean color for study of biological productivity. Countries were asked to nominate speak- ers and to agree to provide their travel to the meeting if the speaker were chosen.

Perhaps one of the most interesting aspects of the meeting were the consultations among delegations about the selection of a new secretary for the Commission. Dr. Ruivo will be retiring at the end of this year, and a number of candidates for the position have been identified. The U.S. delegation, in order to get to know the candidates better, invited each to lunch on different days.

A final decision will be made by the UNESCO Director-General. Frederico Mayor, within the next few months.

A highlight of the meeting was the (no-host) fiftieth birthday party for Lou Brown, held at the Nuit de St. Jean Restaurant. An international group gathered on March 11 to honor Lou and his many contributions to fostering international oceanography over the years.

In this observer's opinion, the discussions and actions taken at the meeting showed a healthy progress toward closer integration of intergovernmental mechanisms with the needs of the research community.

Table of Acronyms not defined in the text:

NOAA - National Oceanic \& Atmospheric Administration

TOGA-Tropical Oceans \& Global Atmosphere

WOCE - World Ocean Circulation Experiment

SCOR - Scientific Committee on Oceanic Research

IGOSS-Integrated Ocean Services System

GIPME - Global Investigation of Pollution in the Marine Environment .

NODC - National Oceanographic Data Center

FAO-IOC-UN-United Nations Food \& Agriculture Organization/Intergovernmental Oceanographic Commission IOC/UN-Joint program between the Intergovernmental Oceanographic Commission and the United Nations Economics \& Technology Branch IOC/WMO-Intergovernmental Oceanographic Commission/World Meteorological Organization

UNESCO-United Nations Educational, Scientific \& Cultural Organization

CCCO-Committee on Climatic Changes \& the Ocean

Contributed by D. James Baker, President, Joint Oceanographic Institutions, Inc.
OC E A N O G R A P H Y
$\mathrm{D}$ uring January, 1988, a contingent of about 120 United States coastal physical oceanographers and a few associates from other disciplines met to consider plans for the next decade and beyond. The group identified important major problems and sought ways to expedite their solution. Tentatively, the emphasis is on mass and momentum exchanges from the surf zone, across the shelf, and out to the open ocean on time scales of hours to years. A summary of the meeting is in preparation, and this report will be broadly circulated to the oceanographic community.

$\mathrm{CoPO}$ is only a first step in creating a coherent plan for coastal oceanography as a whole. A broader plan must be created that encompasses participation of meteorologists and biological. chemical, and geological oceanographers. Long-term measurement programs envisioned by CoPO present a natural opportunity for studies involving all of these disciplines. Over the next years, CoPO leadership will try to coordinate activites with large programs such as WOCE, and with the funding agencies. The detailed CoPO program must take on a focus reflecting high-priority science with substantial interdisciplinary content. These interactions will be initiated by circulation of the CoPO report and by encouraging small, informal workshops.

Further information can be obtained from Kenneth W. Brink, Chairman of the CoPO Science Steering Group, Woods Hole Oceanographic Institution. Woods Hole, MA 02543 (telemail K.BRINK). 